\title{
Cognitive Behavior Modification untuk Menurunkan Prokrastinasi Akademik Siswa Sekolah Menengah Atas
}

(The Effectiveness of Cognitive Behavior Modification to Reduce Academic Procrastination of High School Students)

\author{
Roiyan One Febriani ${ }^{1 *}$, M. Ramli ${ }^{2}$, Nur Hidayah ${ }^{2}$ \\ ${ }^{1}$ Program Studi Pendidikan Guru Madrasah Ibtidaiyah, Fakultas Ilmu Tarbiyah dan Keguruan, \\ Universitas Islam Negeri Maulana Malik Ibrahim Malang, Jl. Gajayana No. 50, Malang, Jawa Timur, 65144 Indonesia \\ ${ }^{2}$ Jurusan Bimbingan dan Konseling, Fakultas Ilmu Pendidikan, Universitas Negeri Malang, \\ Jl. Semarang No. 5, Malang, Jawa Timur, 65145 Indonesia \\ *corresponding author, e-mail: roiyanone@uin-malang.ac.id
}

Article received: April 22 2020 ; revised: May 31 ${ }^{\text {st }} 2020$; accepted: June $3^{\text {rd }} 2020$

\begin{abstract}
Procrastination is a problem that many students experience. This study aimed to investigate the effectiveness of cognitive behavior modification to reduce academic procrastination of high school students. To achieve this goal, this study used a single subject design. Three male students and two female students were selected as research participants using a purposive sampling technique. Data on the rate of procrastination in the baseline 1 (A1), intervention (B) and baseline 2 (A2) phases were obtained from the academic procrastination observation sheet. The data were then analyzed using visual graphic analysis with the split middle method. The analysis showed a decrease in academic procrastination behavior in each student after cognitive behavior modification intervention. This proves that the cognitive behavior modification approach is effective in reducing academic procrastination of high school students.
\end{abstract}

Keywords: academic procrastination; cognitive behavior modification; single subject design

\begin{abstract}
Abstrak: Prokrastinasi merupakan permasalahan yang banyak dialami para siswa. Penelitian ini bertujuan untuk menguji keefektifan cognitive behavior modification untuk menurunkan prokrastinasi akademik siswa sekolah menengah atas (SMA). Untuk mencapai tujuan tersebut, penelitian ini menggunakan rancangan single subject design. Tiga siswa laki-laki dan dua siswa perempuan dipilih sebagai subjek penelitian dengan menggunakan teknik purposive sampling. Data tingkat prokrastinasi pada fase baseline 1 (A1), intervensi (B) dan baseline 2 (A2) diperoleh dari lembar observasi prokrastinasi akademik. Data tersebut kemudian dianalisis menggunakan analisis visual grafik dengan metode split middle. Hasil penelitian menunjukkan penurunan perilaku prokrastinasi akademik pada masing-masing siswa setelah intervensi cognitive behavior modification. Hal ini membuktikan bahwa pendekatan cognitive behavior modification efektif untuk menurunkan prokrastinasi akademik siswa SMA.
\end{abstract}

Kata kunci: prokrastinasi akademik; cognitive behavior modification; single subject design 


\section{PENDAHULUAN}

Prokrastinasi merupakan perilaku yang cenderung melakukan penundaan dalam hal mengawali penyelesaian tugas dengan melakukan aktivitas lain yang tidak bermanfaat sehingga menyebabkan adanya hambatan dalam pengerjaan tugas, tidak selesai tepat pada waktunya, dan sering terlambat (Solomon \& Rothblum, 1984). Prokrastinasi akademik berkaitan dengan aspek pikiran dan perilaku seperti: (a) irrational beliefs, (b) self statement and private self consciouseness, (c) locus of control and learned helplessnesss, serta (d) irrational perfectionism (Ferrari et al, 1995). Steel \& Klingsieck, (2016) mengungkapkan bahwa prokrastinasi akademik biasanya mengacu pada penundaan sukarela yang berkaitan dengan keterlambatan. Berdasarkan beberapa uraian tersebut, diketahui bahwa prokrastinasi akademik merupakan perilaku maladaptif yang berkaitan erat dengan pola pikir siswa.

Pola pikir siswa sangat memengaruhi siswa saat bertindak dalam menyelesaikan tugas akademik. Pola pikir siswa dapat membuat siswa berpikir bahwa menyelesaikan tugas sesegera mungkin adalah pilihan yang terbaik atau justru sebaliknya, yaitu menunda-nunda mengerjakan tugas merupakan hal yang menyenangkan karena dapat melakukan kegiatan lain daripada mengerjakan tugas. Prokrastinasi akademik mengacu pada empat indikator yang menjadi tolak ukur yaitu: menunda untuk menyelesaikan tugas, keterlambatan dalam mengumpulkan tugas, ketidaksesuaian waktu mengerjakan berdasarkan rencana dan kinerja, melakukan aktivitas lain yang lebih menyenangkan (Ferrari et al., 1995).

Sebuah penelitian di salah satu SMA Tangerang menunjukkan bahwa 43,70\% siswa memiliki tingkat prokrastinasi akademik tinggi dan 56,30\% lainnya memiliki prokrastinasi akademik rendah (Utaminingsih \& Setyabudi, 2012). Penelitian lain menyatakan bahwa pada kelompok eksperimen terdapat $3,8 \%$ siswa yang memiliki prokrastinasi akademik rendah, 65,4\% sedang, dan 30,8\% tinggi, sedangkan pada kelompok kontrol terdapat $11,5 \%$ siswa memiliki prokrastinasi akademik rendah, 65,4\% sedang, dan 23,1\% tinggi (Gading, 2014). Munawaroh et al., (2017) memaparkan hasil penelitiannya bahwa $17,2 \%$ pelajar pada salah satu sekolah menengah pertama di Yogyakarta mengalami prokrastinasi tinggi, 77,1\% sedang, dan 5,7 rendah. Beberapa penelitian tersebut menunjukkan bahwa tingkat prokrastinasi siswa masih tergolong tinggi. Sebuah penelitian lain mencoba melihat perbedaan prokrastinasi dari jenis kelamin, hasilnya tingkat prokrastinasi akademik pada siswa laki-laki sejumlah 38,09\% tinggi, 33,34\% sedang, $28,57 \%$ rendah, sedangkan untuk siswa perempuan memiliki tingkat prokrastinasi akademik sejumlah 37,05\% tinggi, 35,32\% sedang dan 27,28\% rendah (Erfantinni et al, 2016).

Berdasarkan hasil wawancara kepada konselor sekolah di salah satu SMA Negeri Kota Malang pada bulan Maret 2016, beberapa siswa melakukan prokrastinasi akademik berupa tidak mengerjakan tugas maupun terlambat dalam mengumpulkan tugas. Pada kesempatan lain, hasil wawancara dengan guru mata pelajaran di salah satu sekolah menengah kejuruan (SMK) Negeri Kota Malang pada bulan Mei 2016 menunjukkan bahwa prokrastinasi akademik juga terjadi di kalangan siswa SMK. Hal tersebut ditunjukkan dengan adanya siswa yang tidak mengumpulkan tugas, mengumpulkan tugas yang hasil nya tidak maksimal, dan pengumpulan tugas melebihi tenggat waktu yang ditentukan. Hal ini senada dengan penelitian yang menunjukkan bahwa prokrastinasi akademik cenderung mengarahkan siswa untuk menggunakan cara terlarang dalam ujian, menyalin pekerjaan rumah dari siswa lain dan membuat atau memalsukan data (Patrzek et al., 2015). Selain memiliki pengaruh terhadap prestasi akademik siswa (Balkis, 2013), prokrastinasi akademik dapat menghambat kesuksesan dalam pengalaman akademik (Park \& Sperling, 2012). Solomon \& Rothblum (1984) mengemukakan dampak lain dari prokrastinasi akademik adalah tugas tidak selesai, atau selesai tetapi hasil yang diperoleh tidak maksimal, karena dikejar deadline.

Hal tersebut menjadi salah satu masalah di kalangan siswa dan berdampak buruk terhadap prestasi akademik serta pembentukan kebiasaan belajar siswa. Apabila hal ini tidak segera diselesaikan maka siswa akan tetap melakukan prokrastinasi akademik, prestasi akademik siswa menjadi tidak optimal, dan pada akhirnya kualitas pendidikan menjadi rendah. Oleh sebab itu, menurunkan tingkat prokrastinasi akademik siswa SMA sangat penting untuk dilakukan guna mewujudkan generasi bangsa yang cerdas dan unggul.

Terdapat beberapa penelitian menggunakan pendekatan tertentu dalam Bimbingan dan Konseling untuk menanggulangi prokrastinasi akademik. Pendekatan tersebut adalah: menggunakan konseling kelompok cognitive behavior (Taneo, 2014), pelatihan kendali diri (Gading, 2014), pelatihan keterampilan berbasis Cognitive Behavioral Theory (Toker \& Avci, 2015), pelatihan keterampilan berpikir positif 
(Moradi, 2017), juga intervensi kelompok psycho-educational berbasis terapi realitas (Çelik \& Odac1, 2018). Penelitian ini menggunakan konseling dengan pendekatan cognitive behavior modification yang melatih siswa mengubah cara belajar pada diri sendiri, sehingga mereka dapat menghadapi masalahnya secara lebih efektif, khususnya yang berkaitan dengan prokrastinasi akademik. Pemilihan pendekatan cognitive behavior modification didasarkan pada prokrastinasi merupakan perilaku maladaptif yang berkaitan erat dengan pola pikir, sedangkan pendekatan cognitif behavior modification adalah pendekatan yang berfokus pada perubahan self declaration negatif menjadi self declaration positif(Lotfi et al, 2011). Penelitian ini bertujuan mengetahui keefektifan cognitive behavior modification untuk menurunkan tingkat prokrastinasi akademik siswa SMA.

\section{METODE}

Rancangan penelitian yang digunakan pada penelitian ini adalah single-subject design dengan desain A-B-A. Desain A-B-A merupakan desain penelitian yang hasil pengolahan datanya dapat digunakan untuk menyelidiki perubahan perilaku, dalam hal ini adalah perilaku prokrastinasi akademik. Desain A-B-A menunjukkan tiga kondisi, yaitu A1 (baseline 1), B (intervensi), dan A2 (baseline 2) pengukuran pasca intervensi dihilangkan atau maintenance. A2 (baseline 2) dimaksudkan sebagai pengontrol intervensi sehingga memungkinkan untuk menyimpulkan adanya hubungan fungsional antara cognitive behavior modification dengan prokrastinasi akademik siswa. Maka dari itu dapat diperoleh hasil yang menjelaskan bahwa perubahan tingkat prokrastinasi akademik disebabkan karena adanya intervensi yang telah diberikan dan bukan dari faktor lain. Tujuan dari mengadaptasi dan menggunakan singlesubject design ini adalah untuk mengontrol dan menentukan bahwa intervensi pendekatan cognitive behavior modification telah menyebabkan terjadinya perubahan dalam menurunkan prokrastinasi akademik siswa.

Pengambilan sampel dilakukan melalui teknik purposive sampling dengan kriteria penjaringan subjek yaitu: (1) tercatat sebagai siswa kelas XI SMA Negeri 5 Malang, (2) teridentifikasi sebagai siswa yang melakukan prokrastinasi akademik tinggi didasarkan pada pengukuran menggunakan skala prokrastinasi, (3) teridentifikasi sebagai siswa yang memiliki ciri prokrastinasi akademik tinggi berdasarkan hasil wawancara dengan konselor. Subjek penelitian terdiri dari lima orang siswa kelas XI SMA Negeri 5 Malang, yaitu dua perempuan dengan inisial CN dan ER serta tiga laki-laki dengan inisial IL, RM, dan RN. Kelima subjek penelitian merupakan siswa jurusan Ilmu Pengetahuan Sosial dengan usia 16-17 tahun.

Instrumen penelitian yang digunakan dalam penelitian ini adalah: (1) instrumen perlakuan/intervensi berupa buku panduan intervensi pendekatan cognitive behavior modification untuk menurunkan prokrastinasi akademik siswa SMA yang didasarkan pada tiga tahapan yaitu: observasi diri, melakukan dialog internal baru, dan belajar keterampilan baru, dan (2) instrumen pengumpulan data yaitu skala prokrastinasi akademik, lembar observasi prokrastinasi akademik, lembar refleksi, serta lembar tugas. Sebelum instrumen perlakuan dan instrumen pengumpul data digunakan dalam penelitian, instrumen terlebih dahulu dinilaikan pada ahli/validasi ahli (expert judgment). Penilaian ahli dilakukan oleh dua orang dosen Universitas Negeri Malang di bidang Bimbingan dan Konseling. Analisis hasil uji ahli menggunakan model kesepakatan (Inter-rater Agreement Model). Berdasarkan hasil analisis penilaian ahli, panduan cognitive behavior modification telah layak untuk dipergunakan dalam proses intervensi.

Prosedur penelitian yang dilakukan adalah: (1) tahap persiapan, meliputi: (a) menyusun dan merevisi bahan perlakuan, (b) uji coba instrumen, (c) izin penelitian, (d) menentukan subjek penelitian, (2) tahap pelaksanaan, meliputi: (a) melaksanakan baseline (A1) yaitu observasi, (b) melaksanakan intervensi, (c) melakukan observasi pada baseline (A2), (3) tahap akhir, meliputi (a) analisis data dan (b) penulisan laporan.

Penelitian ini menggunakan analisis data berupa analisis visual grafik dengan metode split middle. Analisis data visual merupakan hasil dari penginterpretasian data yang tergambar dalam grafik perkembangan perilaku prokrastinasi akademik siswa. Terdapat enam komponen analisis dalam kondisi, yaitu: (1) panjang kondisi, (2) estimasi kecenderungan arah, (3) kecenderungan stabilitas, (4) jejak data, (5) level stabilitas dan rentang, serta (6) level perubahan. Pada analisis antar kondisi mencakup: (1) jumlah variabel yang diubah, (2) perubahan kecenderungan dan efeknya, (3) perubahan stabilitas, 
(4) perubahan level, dan (5) data overlap. Kriteria data tumpang tindih adalah kurang dari $10 \%$ menyatakan intervensi sangat efektif, $10 \%-25 \%$ menyatakan efektif, $25 \%-50 \%$ menyatakan intervensi dipertanyakan, dan lebih dari 50\% menyatakan intervensi tidak efektif.

\section{HASIL}

Hasil pengukuran dan intervensi subjek selama baseline (A1), intervensi (B), dan baseline (A2) dipaparkan dalam analisis individu. Tujuan dari analisis individu adalah untuk mengetahui perkembangan masing-masing subjek. Adapun hasil dari pengukuran observasi kelima subjek penelitian masing-masing selama baseline (A1), intervensi (B), dan baseline (A2) disajikan pada tabel 1.

Selain pengukuran melalui observasi pada setiap baseline (A1), intervensi (B), dan baseline (A2), dilakukan juga pengukuran menggunakan skala prokrastinasi akademik. Hasil pengukuran menggunakan skala prokrastinasi akademik sebelum dan sesudah intervensi disajikan pada tabel 2. Pada tabel 2, diketahui bahwa masing-masing subjek mengalami penurunan prokrastinasi akademik. Selanjutnya, hasil observasi masing-masing subjek digambarkan dalam bentuk grafik dan dianalisis dengan metode split middle.

Gambar 1 menunjukkan perilaku prokrastinasi akademik $\mathrm{CN}$ yang mengalami penurunan sedikit pada (A1). Pada (B) terlihat penurunan yang lebih drastis dari sebelumnya, dan pada (A2) diketahui bahwa ada kecenderungan penurunan perilaku prokrastinasi akademik. Pada analisis dalam kondisi panjang, kondisi (A1) adalah 3, (B) adalah 6, dan (A2) adalah 3. Estimasi kecenderungan arah (A1), (B), dan (A2) yaitu meningkat (+). Kecenderungan stabilitas pada (A1) diperoleh nilai prokrastinasi

Tabel 1. Hasil Pengukuran Observasi Prokrastinasi Akademik Masing-Masing Subjek

\begin{tabular}{cccccccccccccc}
\hline No. & Konseli & \multicolumn{4}{c}{ Baseline (A1) } & \multicolumn{4}{c}{ Intervensi (B) } & \multicolumn{3}{c}{ Baseline (A2) } \\
\cline { 2 - 16 } & & Sesi & Sesi & Sesi & Sesi & Sesi & Sesi & Sesi & Sesi & Sesi & Sesi & Sesi & Sesi \\
& & $\mathbf{1}$ & $\mathbf{2}$ & $\mathbf{3}$ & $\mathbf{1}$ & $\mathbf{2}$ & $\mathbf{3}$ & $\mathbf{4}$ & $\mathbf{5}$ & $\mathbf{6}$ & $\mathbf{1}$ & $\mathbf{2}$ & $\mathbf{3}$ \\
\hline 1 & CN & 72 & 72 & 69 & 64 & 58 & 53 & 49 & 48 & 43 & 36 & 28 & 25 \\
2 & ER & 72 & 72 & 70 & 64 & 60 & 53 & 50 & 48 & 45 & 39 & 31 & 26 \\
3 & IL & 72 & 72 & 72 & 69 & 63 & 58 & 56 & 50 & 48 & 42 & 35 & 29 \\
4 & RM & 72 & 72 & 69 & 65 & 60 & 54 & 52 & 49 & 45 & 36 & 30 & 25 \\
5 & RN & 71 & 70 & 70 & 62 & 58 & 54 & 49 & 46 & 38 & 31 & 27 & 24 \\
\hline
\end{tabular}

Tabel 2. Hasil Pengisian Instrumen Skala Prokrastinasi Akademik Sebelum dan Sesudah Intervensi

\begin{tabular}{ccc}
\hline Konseli & Sebelum Intervensi & Sesudah Intervensi \\
\hline CN & 130 & 72 \\
ER & 129 & 72 \\
IL & 134 & 73 \\
RM & 131 & 73 \\
RN & 128 & 69 \\
\hline
\end{tabular}

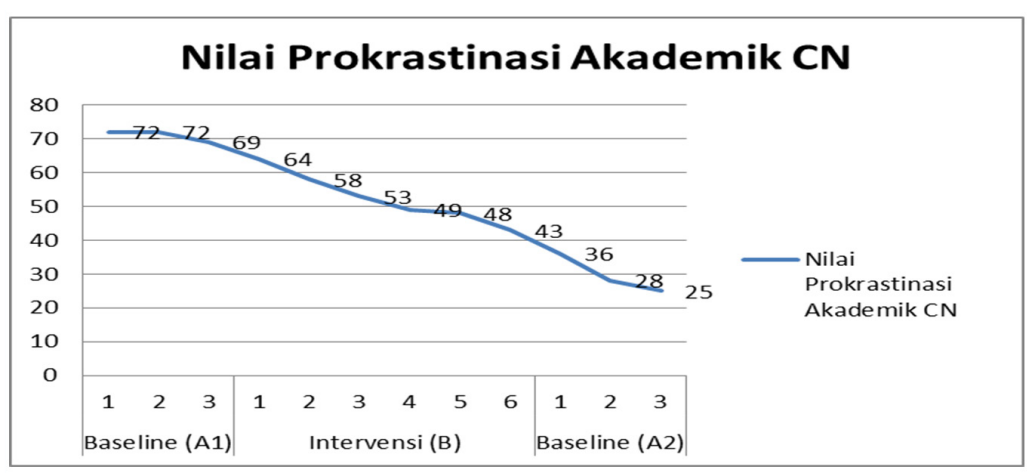

Gambar 1. Grafik Perkembangan Tingkat Prokrastinasi Akademik Subjek CN 
akademik 72, 72, dan 69. Pada (B) diperoleh nilai prokrastinasi akademik 64, 58, 53, 49, 48, dan 43. Pada (A2) diperoleh nilai prokrastinasi akademik 36, 28, dan 25. Kecenderungan stabilitas (trend) positif dari variabel (A1) ke variabel (B) menjadi stabil (A2). Jejak data (A1) menurun (+), (B) menurun (+), dan (A2) menurun (+). Level stabilitas dan rentang (A1) 72-69, (B) 64-43, dan (A2) 36-25. Perubahan level pada (A1) adalah 72-69 (+3), (B) adalah 64-43 (+21), dan (A2) adalah 36-25 (+11).

Jumlah variabel yang diubah pada analisis antar kondisi subjek $\mathrm{CN}$ adalah satu variabel, yaitu prokrastinasi akademik. Perubahan kecenderungan arah dan efeknya pada (A1) menunjukkan penurunan yang rendah. Sedangkan pada (B) dan (A2) mengalami penurunan yang lebih drastis dari (A). Hal ini menunjukkan bahwa intervensi berpengaruh positif terhadap variabel yang diubah. Perubahan stabilitas (A1) termasuk dalam kategori rendah. Pada (B) dan (A2) perubahan stabilitas termasuk dalam kategori tinggi. Perubahan stabilitas positif dari variabel (A1) ke variabel (B) menjadi stabil (A2). Hal ini menunjukkan bahwa prokrastinasi akademik subjek $\mathrm{CN}$ mengalami penurunan. Perubahan level nilai prokrastinasi akademik subjek $\mathrm{CN}$ ditentukan dengan menghitung selisih antara data poin (A) sesi terakhir dan sesi pertama pada (B) yaitu 69-64 maka diperoleh (+5). Sedangkan selisih data poin dari (B) sesi terakhir dan sesi pertama (A2) yaitu 43-36 maka diperoleh (+7). Data tumpang tindih (overlap) (A1) prokrastinasi akademik memiliki batas 81,1 dan batas bawah sebesar 60,2. Data poin (B) dan (A2) yang berada pada rentang (A1) tidak ada. Persentase data yang tumpang tindih adalah $0 \%$. Hal ini berarti intervensi yang diberikan sangat efektif karena $<10 \%$.

Gambar 2 menunjukkan bahwa perilaku prokrastinasi akademik ER hanya mengalami penurunan sedikit pada (A1). Pada (B) terlihat penurunan yang lebih drastis dari sebelumnya, dan pada (A2) diketahui bahwa ada kecenderungan penurunan perilaku prokrastinasi akademik.

Pada analisis dalam kondisi panjang, kondisi (A1) adalah 3, (B) adalah 6, dan (A2) adalah 3. Estimasi kecenderungan arah (A1), (B), dan (A2) yaitu meningkat (+). Kecenderungan stabilitas (A1) diperoleh nilai prokrastinasi akademik 72, 72, dan 70. Pada (B) diperoleh nilai prokrastinasi akademik 64, 60, 53, 50, 48, dan 45. Pada (A2) diperoleh nilai prokrastinasi akademik 39, 31, dan 26. Kecenderungan stabilitas (trend) positif dari variabel (A1) ke variabel (B) menjadi stabil (A2). Jejak data pada (A1) menurun $(+)$, (B) menurun $(+)$, dan (A2) menurun $(+)$. Level stabilitas dan rentang pada (A1) 72-70, (B) 64-45, dan (A2) 39-26. Perubahan level (A1) adalah 72-70 (+2), (B) adalah 64-45 (+19), dan (A2) adalah $39-26(+13)$.

Jumlah variabel yang diubah pada analisis antar kondisi subjek ER adalah satu variabel, yaitu prokrastinasi akademik. Perubahan kecenderungan arah dan efeknya pada (A1) menunjukkan penurunan yang rendah. Sedangkan pada (B) dan (A2) mengalami penurunan yang lebih drastis dari (A). Hal ini menunjukkan bahwa intervensi berpengaruh positif terhadap variabel yang diubah. Perubahan stabilitas (A1) termasuk dalam kategori rendah. Pada (B) dan (A2) termasuk dalam kategori tinggi. Perubahan stabilitas positif dari variabel (A1) ke variabel (B) menjadi stabil (A2). Hal ini menunjukkan bahwa prokrastinasi akademik subjek ER mengalami penurunan. Perubahan level nilai prokrastinasi akademik subjek ER ditentukan dengan menghitung selisih antara data poin (A) sesi terakhir dan sesi pertama (B) yaitu 70-64 maka diperoleh (+6). Sedangkan selisih data poin dari (B) sesi terakhir dan sesi pertama (A2) yaitu 45-39 maka diperoleh (+6). Data tumpang tindih (overlap) (A1) prokrastinasi akademik memiliki batas 82,1 dan batas bawah sebesar 60,5. Data poin (B) dan (A2) yang berada pada rentang (A1) tidak ada. Persentase data yang tumpang tindih adalah $0 \%$. Hal ini berarti intervensi yang diberikan sangat efektif karena $<10 \%$.

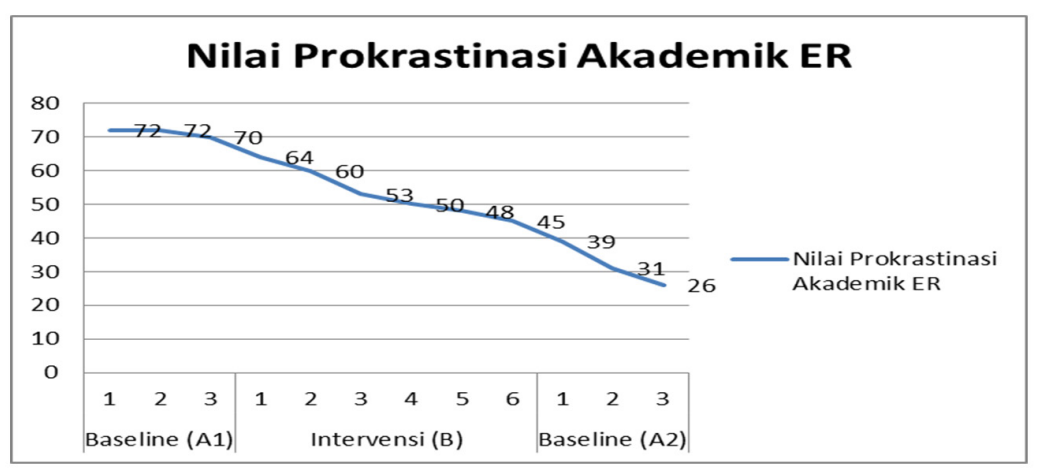

Gambar 2. Grafik Perkembangan Tingkat Prokrastinasi Akademik Subjek ER 


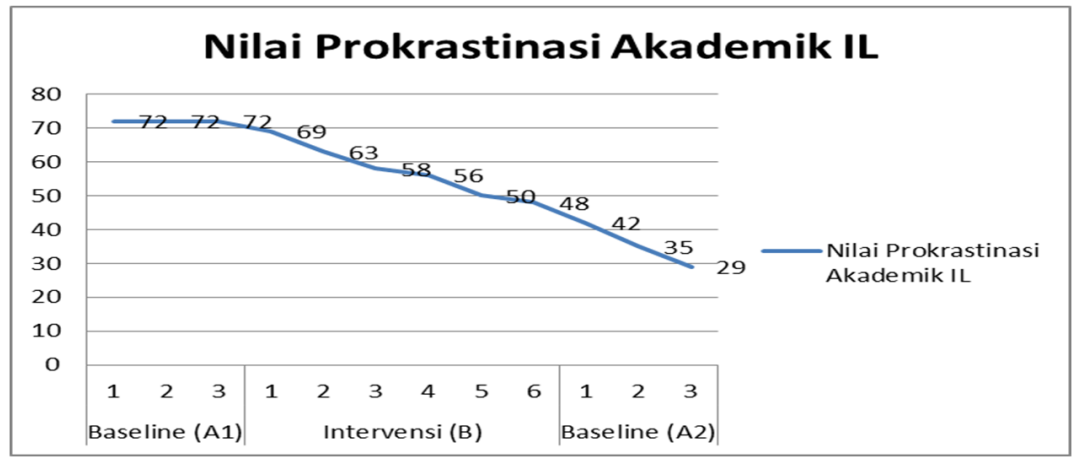

Gambar 3. Grafik Perkembangan Tingkat Prokrastinasi Akademik Subjek IL

Gambar 3 menunjukkan bahwa perilaku prokrastinasi akademik IL hanya mengalami penurunan sedikit pada (A1). Sedangkan pada (B) sudah menunjukkan adanya penurunan yang drastis dari sebelumnya, pada (A2) diketahui bahwa ada kecenderungan perilaku prokrastinasi akademik yang menurun.

Pada analisis dalam kondisi panjang, kondisi (A1) adalah 3, (B) adalah 6, dan (A2) adalah 3. Estimasi kecenderungan arah (A1), (B), dan (A2) yaitu meningkat (+). Kecenderungan stabilitas (A1) diperoleh nilai prokrastinasi akademik 72, 72, dan 72. Pada (B) diperoleh nilai prokrastinasi akademik 69, 63, $58,56,50$, dan 48. Pada (A2) diperoleh nilai prokrastinasi akademik 42, 35, dan 29. Kecenderungan stabilitas (trend) positif dari variabel (A1) ke variabel (B) menjadi stabil (A2). Jejak data pada (A1) tetap $(=)$, (B) menurun $(+)$, dan (A2) menurun (+). Level stabilitas dan rentang (A1) 72-72, (B) 69-48, dan (A2) 42-29. Perubahan level (A1) adalah 72-72 (0), (B) adalah 69-48 (+19), dan (A2) adalah 42-29 $(+13)$.

Jumlah variabel yang diubah pada analisis antar kondisi subjek IL adalah satu variabel, yaitu prokrastinasi akademik. Perubahan kecenderungan arah dan efeknya pada (A1) menunjukkan data yang tetap. Sedangkan pada (B) dan (A2) mengalami penurunan yang lebih tinggi dari (A1). Hal ini menunjukkan bahwa intervensi memiliki pengaruh positif terhadap variabel yang diubah. Perubahan stabilitas pada (A1) termasuk dalam kategori rendah. Pada (B) dan (A2) termasuk dalam kategori tinggi. Perubahan stabilitas positif dari variabel (A1) ke variabel (B) menjadi stabil (A2). Hal ini menunjukkan bahwa prokrastinasi akademik subjek IL mengalami penurunan. Perubahan level nilai prokrastinasi akademik subjek IL ditentukan dengan menghitung selisih antara data poin (A) sesi terakhir dan sesi pertama (B) yaitu 72-69 maka diperoleh (+3). Sedangkan selisih data poin dari (B) sesi terakhir dan sesi pertama (A2) yaitu 48-42 maka diperoleh $(+6)$. Data tumpang tindih (overlap) (A1) prokrastinasi akademik memiliki batas 82,8 dan batas bawah sebesar 61,2. Data poin (B) dan (A2) yang berada pada rentang (A1) tidak ada. Persentase data yang tumpang tindih adalah $0 \%$. Hal ini berarti intervensi yang diberikan sangat efektif karena $<10 \%$.

Gambar 4 menunjukkan bahwa perilaku prokrastinasi akademik RM hanya mengalami penurunan sedikit pada (A1). Pada (B) perilaku prokrastinasi terlihat menurun drastis, dan pada (A2) diketahui bahwa ada perilaku prokrastinasi akademik cenderung menurun.

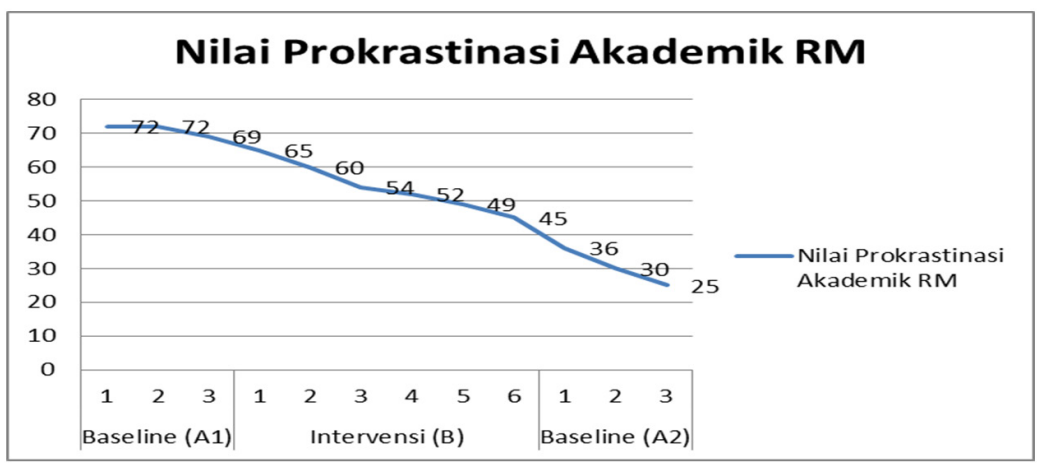

Gambar 4. Grafik Perkembangan Tingkat Prokrastinasi Akademik Subjek RM 
Pada analisis dalam kondisi panjang, kondisi (A1) adalah 3, (B) adalah 6, dan (A2) adalah 3. Estimasi kecenderungan arah (A1), (B), dan (A2) yaitu meningkat (+). Kecenderungan stabilitas (A1) diperoleh nilai prokrastinasi akademik 72, 72, dan 69. Pada (B) diperoleh nilai prokrastinasi akademik 65, 60, 54, 52, 49, dan 45. Pada (A2) diperoleh nilai prokrastinasi akademik 36, 30, dan 25. Kecenderungan stabilitas (trend) positif dari variabel (A1) ke variabel (B) menjadi stabil (A2). Jejak data (A1) menurun $(+)$, (B) menurun $(+)$, dan (A2) menurun $(+)$. Level stabilitas dan rentang (A1) 72-69, (B) 65-48, dan (A2) 36-25. Perubahan level (A1) adalah 72-69 (+3), (B) adalah 65-45 (+20), dan (A2) adalah 36-25 $(+11)$.

Jumlah variabel yang diubah pada analisis antar kondisi subjek RM adalah satu variabel, yaitu prokrastinasi akademik. Perubahan kecenderungan arah dan efek cognitive behavior modification pada (A1) menunjukkan penurunan prokrastinasi akademik yang rendah. Sedangkan pada (B) dan (A2) prokrastinasi akademik mengalami penurunan yang lebih drastis dari (A). Hal ini menunjukkan bahwa intervensi menunjukkan pengaruh positif terhadap variabel yang diubah. Perubahan stabilitas (A1) termasuk dalam kategori rendah. Pada (B) dan (A2) termasuk dalam kategori tinggi. Perubahan stabilitas positif dari variabel (A1) ke variabel (B) menjadi stabil (A2). Hal ini menunjukkan bahwa prokrastinasi akademik subjek RM mengalami penurunan. Perubahan level nilai prokrastinasi akademik subjek RM ditentukan dengan menghitung selisih antara data poin (A) sesi terakhir dan sesi pertama pada (B) yaitu 69-65 maka diperoleh (+4). Sedangkan selisih data poin dari (B) sesi terakhir dan sesi pertama (A2) yaitu 45-36 maka diperoleh (+9). Data tumpang tindih (overlap) (A1) prokrastinasi akademik memiliki batas 81,8 dan batas bawah sebesar 60,2. Data poin pada (B) dan (A2) yang berada pada rentang (A1) tidak ada. Persentase data yang tumpang tindih adalah $0 \%$. Hal ini berarti intervensi yang diberikan sangat efektif karena $<10 \%$.

Gambar 5 menunjukkan bahwa perilaku prokrastinasi akademik RN hanya mengalami penurunan sedikit pada (A1). Pada (B), perilaku prokrastinasi akademik mengalami penurunan yang drastis dari sebelumnya, pada (A2) diketahui bahwa perilaku prokrastinasi akademik cenderung menurun.

Pada analisis dalam kondisi panjang, kondisi (A1) adalah 3, (B) adalah 6, dan (A2) adalah 3. Estimasi kecenderungan arah (A1), (B), dan (A2) yaitu meningkat (+). Kecenderungan stabilitas pada (A1) diperoleh nilai prokrastinasi akademik 71, 70, dan 70. Pada (B) diperoleh nilai prokrastinasi akademik 62, 58, 54, 49, 46, dan 38. Pada (A2) diperoleh nilai prokrastinasi akademik 31, 27, dan 24. Kecenderungan stabilitas (trend) positif dari variabel (A1) ke variabel (B) menjadi stabil (A2). Jejak data (A1) menurun $(+)$, (B) menurun $(+)$, dan (A2) menurun $(+)$. Level stabilitas dan rentang (A1) 71-70, (B) 62-38, dan (A2) 31-24. Perubahan level (A1) adalah 71-70 (+1), (B) adalah 62-38 (+24), dan (A2) adalah 31-24 (+7).

Jumlah variabel yang diubah pada analisis antar kondisi subjek RN adalah satu variabel, yaitu prokrastinasi akademik. Perubahan kecenderungan arah dan efek cognitive behavior modification pada (A1) menunjukkan penurunan prokrastinasi akademik yang drastis. Pada (B) dan (A2) prokrastinasi akademik turun lebih drastis daripada (A). Hal ini menunjukkan bahwa intervensi memberikan pengaruh positif terhadap variabel yang diubah. Perubahan stabilitas (A1) termasuk dalam kategori rendah. Pada (B) dan (A2) termasuk dalam kategori tinggi. Perubahan stabilitas positif dari variabel (A1) ke variabel (B) menjadi stabil (A2). Hal ini menunjukkan bahwa prokrastinasi akademik subjek RN mengalami penurunan. Perubahan level nilai prokrastinasi akademik subjek RN ditentukan dengan menghitung

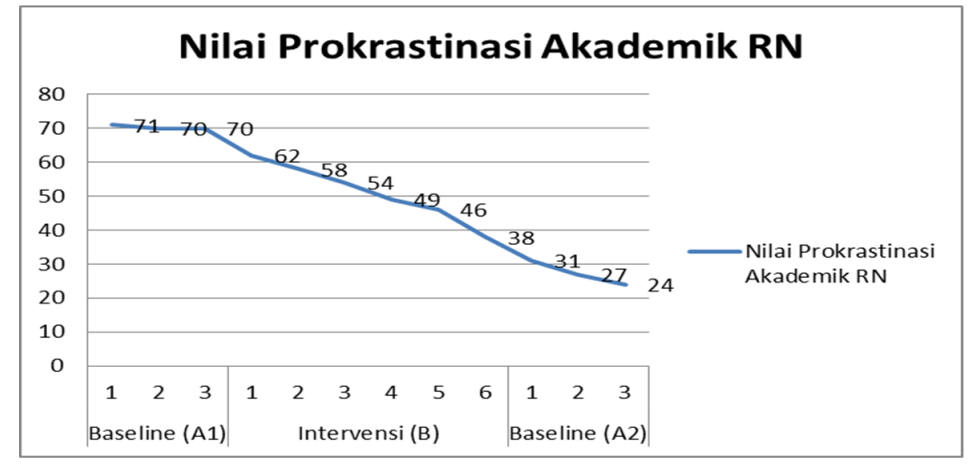

Gambar 5. Grafik Perkembangan Tingkat Prokrastinasi Akademik Subjek RN 
selisih antara data poin (A) sesi terakhir dan sesi pertama pada (B) yaitu 70-62 maka diperoleh (+8). Sedangkan selisih data poin dari (B) sesi terakhir dan sesi pertama (A2) yaitu 38-31 maka diperoleh (+7). Data tumpang tindih (overlap) (A1) prokrastinasi akademik memiliki batas 80,95 dan batas bawah sebesar 59,65. Data poin pada (B) dan (A2) yang berada pada rentang (A1) tidak ada. Persentase data yang tumpang tindih adalah $0 \%$. Hal ini berarti intervensi yang diberikan sangat efektif karena $<10 \%$.

\section{PEMBAHASAN}

Penelitian ini bertujuan untuk mengetahui keefektifan pendekatan cognitive behavior modification untuk menurunkan prokrastinasi akademik siswa SMA. Intervensi berupa konseling kelompok dengan pendekatan cognitive behavior modification diberikan kepada lima siswa yang memiliki prokrastinasi akademik tinggi. Sebelum intervensi menggunakan pendekatan cognitive behavior modification dilakukan, prokrastinasi akademik kelima subjek berada pada kategori tinggi dan sesudah diberikan intervensi menggunakan pendekatan cognitive behavior modification, prokrastinasi akademik kelima subjek penelitian mengalami penurunan yang signifikan, meskipun penurunannya bervariasi antar masing-masing subjek.

Proses intervensi cognitive behavior modification dilakukan melalui tiga tahapan, yaitu: observasi diri, memulai dialog internal baru, dan belajar keterampilan baru (Lotfi et al., 2011). Pada tahap melakukan observasi diri, siswa didorong untuk melakukan eksplorasi diri sehingga menjadi pengamat yang lebih baik terhadap perilakunya sendiri (Serrano, 2009). Melalui identifikasi kondisi yang mendorong siswa melakukan penundaan atau mendapatkan motivasi terhadap tugas-tugas akademiknya, siswa akan lebih mengenal kelemahan dan kelebihan dirinya. Tahap observasi diri pada intervensi cognitive behavior modification, sejalan dengan penelitian (Park \& Sperling, 2012) bahwa siswa memantau dan mengevaluasi kinerjanya. Melalui observasi dan pemantauan, siswa dapat memilah perilaku yang positif dan perilaku yang negatif.

Tahap kedua adalah memulai dialog internal baru. Pada tahap ini, siswa mulai mendengarkan dialog internal dalam diri dan menggali karakteristik pernyataan negatif yang diharapkan dapat dirubah dengan dialog internal yang positif (Lotfi et al., 2011). Prokrastinasi akademik merupakan perilaku maladaptif yang berhubungan erat dengan kognitif siswa. Pendekatan cognitive behavior modification berfokus pada perubahan self declaration negatif menjadi self declaration positif (Lotfi et al, 2011). Hal ini sejalan dengan penelitian yang mengemukakan bahwa para siswa diajarkan mengenali pemikiran yang salah yaitu pemikiran irasional dan menggantinya dengan pemikiran yang lebih rasional (Moradi, 2017). Senada dengan inti intervensi cognitive restructuring pada penelitian Larsen et al., (2019) yang menyatakan bahwa cognitive restructuring adalah teknik terapi kognitif yang memungkinkan seseorang mengidentifikasi keyakinan negatif dan irasional kemudian menggantinya dengan pernyataan rasional berbasis fakta. Pada penelitian ini, memulai dialog internal baru membantu siswa mengubah dialog internal negatif menjadi dialog internal positif dengan memilah pemikiran atau pernyataan negatif yang ada pada diri siswa kemudian dirubah menjadi pemikiran atau pernyataan positif yang membuat siswa termotivasi untuk mengubah perilaku prokrastinasi akademiknya.

Tahap ketiga, siswa diajak untuk mempelajari keterampilan baru. Pada tahap ini, siswa membuat sejumlah keterampilan-keterampilan efektif untuk merubah perilaku negatif menjadi perilaku positif dengan menunjukkan sikap atau tindakan yang tidak melakukan prokrastinasi akademik. Pendekatan cognitive behavior modification melibatkan perubahan kognitif yang diimplementasikan pada perubahan perilaku, sejalan dengan penelitian Serrano, (2009) yang mengungkapkan bahwa masalah siswa selalu dikaitkan dengan pikiran negatifnya dan berakibat pada terbentuknya perilaku. Intervensi ini merupakan pendekatan yang digunakan untuk mengubah perilaku yang maladaptif menjadi perilaku yang adaptif (Yonita \& Karneli, 2019). Untuk cognitive behavior modification, cara siswa mengartikan perubahan perilaku yang telah ia buat akan memengaruhi bagaimana perilaku baru itu digeneralisasikan dan dipertahankan (Serrano, 2009). Setelah melalui serangkaian tahapan cognitive behavior modifcation, siswa mampu mempertahankan perilaku positif yaitu tidak melakukan prokrastinasi akademik.

Pendekatan cognitive behavior modification mampu untuk menurunkan prokrastinasi akademik siswa SMA karena dalam proses intervensi siswa dituntut untuk menyadari pikiran-pikiran negatif yang terjadi pada dirinya agar dapat diubah menjadi pikiran yang positif sehingga siswa dapat mengimplementasikannya dalam bentuk perilaku tidak menunda-nunda dalam hal akademik. Pada 
penelitian ini, bentuk perilaku tidak menunda-nunda ditunjukkan dengan perilaku mengerjakan tugas sepulang sekolah, mengumpulkan tugas tepat waktu, dan mematikan handphone ketika mengerjakan tugas. Pada proses intervensi, subjek ER dan CN menunjukkan pemikiran irasional. ER merasa takut gagal jika mengerjakan tugas yang sulit dan $\mathrm{CN}$ takut mendapatkan nilai buruk setelah mengerjakan tugas dengan maksimal. Ketakutan merupakan suatu kondisi psikologis karena adanya kekhawatiran yang berkelanjutan, yang muncul karena inner conflict dan perasaan yang tidak menentu (Aziz, 2015).

Penelitian ini ditunjang oleh penelitian sebelumnya bahwa cognitive behavior modification efektif untuk meningkatkan prestasi belajar siswa SMP (Zyromski \& Joseph, 2008). Lotfi et al (2011) menemukan bahwa cognitive behavior modification efektif untuk mengurangi kecemasan siswa dalam mengikuti tes. Fajarwati, (2015) mengemukakan bahwa cognitive behavior modification efektif untuk meningkatkan motivasi berprestasi siswa SMP, hal tersebut senada dengan penelitian Hengudomsub et al, (2016) yang menunjukkan bahwa cognitive behavior modification efektif untuk menurunkan stres. Meskipun demikian, penelitian ini memiliki perbedaan dengan penelitian terdahulu dimana cognitive behavior modification diujikan pada kelompok eksperimen dan kelompok kontrol. Pada penelitian ini, cognitive behavior modification hanya diujikan pada kelompok eksperimen karena tidak ada kelompok kontrol. Kekurangan yang ada pada penelitian ini adalah cognitive behavior modification hanya diujikan pada siswa jurusan ilmu pendidikan sosial dan diobservasi pada beberapa matapelajaran. Kelebihan penelitian ini adalah analisis data yang berdasarkan perkembangan perubahan perilaku masing-masing subjek penelitian setelah diberikan intervensi.

Pengukuran keefektifan cognitive behavior modification dalam penelitian ini dilakukan dengan melihat hasil analisis visual dengan metode split middle yang telah dipaparkan pada hasil penelitian mulai dari baseline (A1), intervensi (B), dan baseline (A2) yang ditunjukkan oleh grafik. Berdasarkan data hasil analisis visual maka dapat diketahui bahwa terdapat penurunan tingkat prokrastinasi akademik menggunakan cognitive behavior modification, hal ini disebabkan oleh beberapa faktor, diantaranya merupakan dampak dari desain penelitian yang digunakan yaitu single subject design (SSD), intervensi dengan pendekatan cognitive behavior modification, dan kondisi subjek itu sendiri. Uraian diatas telah membuktikan bahwa pendekatan cognitive behavior modification efektif untuk menurunkan prokrastinasi akademik siswa SMA.

\section{SIMPULAN}

Pendekatan cognitive behavior modification efektif untuk menurunkan prokrastinasi akademik siswa SMA. Penurunan prokrastinasi disebabkan adanya intervensi konseling kelompok yang berfokus merubah pemikiran negatif menjadi perilaku positif menggunakan cognitive behavior modification dengan membantu siswa mengobservasi diri, melakukan dialog internal baru, dan belajar keterampilan baru untuk menjadi individu yang lebih bertanggung jawab terhadap tugas-tugas akademiknya.

\section{DAFTAR RUJUKAN}

Alberto, P., \& Troutman, A. C. (2009). Applied behavior analysis for teachers.

Aziz, R. (2015). Model perilaku prokrastinasi akademik mahasiswa pascasarjana. Journal of Islamic Education, 1(2), 269-291.

Balkis, M. (2013). The relationship between academic procrastination and students' burnout. Hacettepe Üniversitesi Eğitim Fakültesi Dergisi, 28(28-1).

Çelik, Ç. B., \& Odacı, H. (2018). Psycho-educational group intervention based on reality therapy to cope with academic procrastination. Journal of Rational-Emotive \& Cognitive-Behavior Therapy, 36(3), 220-233.

Erfantinni, I. H., Purwanto, E., \& Japar, M. (2016). Konseling kelompok cognitive-behavior therapy dengan teknik cognitive restructuring untuk mereduksi prokrastinasi akademik. Jurnal Bimbingan Konseling, 5(2), 119-125.

Fajarwati, R. (2015). Keefektifan pendekatan cognitive behavior modification (CBM) untuk meningkatkan motivasi berprestasi siswa sekolah menengah pertama (SMP).

Ferrari, J. R., Johnson, J. L., \& McCown, W. G. (1995). Procrastination and task avoidance: Theory, research, and treatment. Springer Science \& Business Media.

Gading, I. K. (2014). Pengaruh pelatihan kendali diri dan jenis kelamin terhadap perilaku prokrastinasi akademik siswa SMP. 
Hengudomsub, P., Kangchai, W., Pathumarak, N., \& Paokanha, R. (2016). The effect of cognitive behavior modification program on stress among caregivers of older adults with Dementia. Thai Pharmaceutical and Health Science Journal-วารสาร ไทย เภสัชศาสตร์ และ วิทยาการ สุขภาพ, 11(1), 1-9.

Larsen, K. D., Shrestha, S., \& Jones, K. (2019). Effects of cognitive restructuring techniques on physical activity in older adults. J Pub Health Issue Pract 3: 141. https://doi.org/10.33790/jphip1100141

Lotfi, S., Eizadi-fard, R., Ayazi, M., \& Agheli-Nejad, M. A. (2011). The effect of Meichenbaum's cognitive behaviour modification therapy on reduction of test anxiety symptoms in high school girls. Procedia-Social and Behavioral Sciences, 30, 835-838.

Moradi, S. (2017). The effectiveness of positive thinking skills on academic procrastination of high school female students Kermanshah City. Interdisciplinary Journal of Virtual Learning in Medical Sciences, 8(1).

Munawaroh, M. L., Alhadi, S., \& Saputra, W. N. E. (2017). Tingkat prokrastinasi akademik siswa Sekolah Menengah Pertama Muhammadiyah 9 Yogyakarta. Jurnal Kajian Bimbingan dan Konseling, 2(1), 26-31.

Park, S. W., \& Sperling, R. A. (2012). Academic procrastinators and their self-regulation. Psychology, 3(1), 12-23.

Patrzek, J., Sattler, S., van Veen, F., Grunschel, C., \& Fries, S. (2015). Investigating the effect of academic procrastination on the frequency and variety of academic misconduct: A panel study. Studies in Higher Education, 40(6), 1014-1029.

Serrano, J. (2009). Reflexiones sobre la" modificación cognitiva de la conducta". Quaderns de Psicologia, 17, $39-57$.

Solomon, L. J., \& Rothblum, E. D. (1984). Academic procrastination: Frequency and cognitive-behavioral correlates. Journal of Counseling Psychology, 31(4), 503.

Steel, P., \& Klingsieck, K. B. (2016). Academic procrastination: Psychological antecedents revisited. Australian Psychologist, 51(1), 36-46.

Sunanto, J., Takeuchi, K., \& Nakata, H. (2005). Pengantar penelitian dengan subjek tunggal. Universitas Tsukuba: Crice.

Taneo, J. (2014). Keefektifan konseling kelompok cognitive behavior untuk mereduksi pola pikir prokrastinasi akademik siswa SMA.

Toker, B., \& Avci, R. (2015). Effect of cognitive-behavioral-theory-based skill training on academic procrastination behaviors of university students. Educational Sciences: Theory and Practice, 15(5), 1157-1168.

Utaminingsih, S., \& Setyabudi, I. (2012). Tipe kepribadian dan prokrastinasi akademik pada siswa SMA "X" Tangerang. Jurnal Psikologi Esa Unggul, 10(01), 127006.

Yonita, E. N., \& Karneli, Y. (2019). The effectiveness of the cognitive behavior modification approach with group settings to reduce bullying behavior. Jurnal Neo Konseling, 1(3).

Zyromski, B., \& Joseph, A. E. (2008). Utilizing cognitive behavioral interventions to positively impact academic achievement in middle school students. Journal of School Counseling, 6(15), n15. 